\title{
ORANG REJANG DAN HUKUM ADATNYA : TAFSIRAN ATAS KELPEAK UKUM ADAT NGEN CA'O KUTEI JANG KABUPATEN REJANG LEBONG
}

\author{
Silvia Devi ${ }^{1}$ \\ Received Article: 5 Oktober 2016 \\ Accepted Article:15 November 2016
}

\begin{abstract}
This study aims to explain about Rejang People in their customary law which according to Kelpeak Ukum Adat Ngen Ca'o Kutei Jang. As the majority ethnic who inhabits the area of Rejang Lebong, it is not denied if the positive law is so enacted remembering the diversity of migrants in Rejang Lebong today. However, the unique of Rejang people today is still holding tight to their customary law in their society life despite that the positive law is still applied. As for their guidelines on customary law contained in Kelpeak Ukum Adat Ngen Ca'o Kutei Jang. The traditional institution which has important role in implementing the guidelines of customary laws in solving various problems in society is Jenang kutai or village judge. The method of this research is qualitative method by collecting data such as literary study, interview the informant and field observation as well. The results of this study show that the role of Jenang Kutai or village judge in Rejang Lebong really have an active role in solving every problem in society. The issue is not only experienced by certain ethnic groups in society, but they all blend together to interact Rejang People as a form of family ligament. As for the implications of the application of customary law with the role of Jenang Kutai sightings of harmony in society, because every issue will be resolved in a peaceful way so it will not cause rancor among the people.
\end{abstract}

Keywords: Rejang people, customary law, Kelpeak Ukum Adat Ngen Ca'o Kutei Jang

Abstrak

Kajian ini bertujuan untuk menjelaskan tentang Orang Rejang dalam hukum adatnya berdasarkan Kelpeak Ukum Adat Ngen Ca'o Kutei Jang. Sebagai sebuah suku bangsa yang mayoritas mendiami daerah Kabupaten Rejang Lebong tidak dipungkiri jika hukum positif sangat diberlakukan mengingat beragamnya penduduk pendatang di Kabupaten Rejang Lebong saaat ini. Namun begitu, ternyata uniknya Orang Rejang sampai saat ini justru semakin memegang erat hukum adatnya dalam kehidupan bermasyarakat meskipun hukum positif tetap diberlakukan. Adapun pedoman mereka atas hukum adat tersebut terdapat pada Kelpeak Ukum Adat Ngen Ca'o Kutei Jang Kabupaten Rejang Lebong. Lembaga adat yang sangat berperan dalam melaksanakan pedoman hukum adat ini dalam menyelesaikan berbagai persoalan di tengah masyarakat adalah jenang kutai atau hakim desa. Metode penelitian adalah metode kualitatif dengan teknik pengumpulan data berupa studi literatur dan wawancara dengan informan serta observasi di lapangan. Hasil kajian ini memperlihatkan bahwa peran jenang kutei atau hakim desa di Kabupaten Rejang Lebong sangat memiliki peran yang aktif dalam menyelesaikan setiap persoalan di tengah masyarakat. Persoalan tidak hanya yang dialami oleh suku-suku tertentu di tengah masyarakat, tetapi mereka semua yang berbaur berinteraksi bersama Orang Rejang sebagai sebuah bentuk ikatan keluarga. Adapun implikasi dari penerapan hukum adat dengan peran jenang kutei terlihatnya kerukunan di tengah masyarakat, karena setiap ada persoalan akan diselesaikan dengan cara damai sehingga tidak menimbulkan dendam diantara masyarakat.

Kata kunci: Orang Rejang, hukum adat, Kelpeak Ukum Adat Ngen Ca'o Kutei Jang

\footnotetext{
${ }^{1}$ Penulis adalah Fungsional Peneliti di Balai Pelestarian Nilai Budaya (BPNB) Sumatera Barat Orang Rejang Dan Hukum Adatnya 


\section{A. PENDAHULUAN}

$\mathrm{S}$ etiap masyarakat yang terdiri dari berbagai macam suku bangsa memiliki ikatan dengan alam serta lingkungannya. Masyarakat tersebut mem bentuk sebuah konsensus guna mencapai suatu ketertiban dalam berinteraksi di kelompok masyarakatnya. Hal ini dikare nakan setiap masyarakat memiliki sejumlah keinginan dan jika tidak dibuat suatu kesepakatan maka bukan tidak mungkin akan terjadi berbagai konflik kepentingan.

Hidup bermasyarakat harus mema tuhi etika atau norma hidup bermasyarakat. Tatacara dalam menjalankan hubungan sosial dalam suatu masyarakat saat ini memang tidak selalu sama dengan masa lalu. Akan tetapi jika dibiarkan masyarakat berlaku semaunya ditambah lagi dengan bebasnya arus negatif yang mengalir dari semakin tingginya tingkat teknologi dan arus informasi, maka bukan tidak mungkin akan terjadi berbagai perilaku yang menyimpang.

Era globalisasi sekarang ini tidak bisa disikapi secara apatis, justru harus disikapi secara pendekatan bermasyarakat serta empatis. Hal ini dikarenakan jika semakin tinggi tingkat individualitas diantara anggota masyarakat maka akan mem berikan dampak negatif. Padahal hubungan sosial harus selalu dibina agar terbentuk hubungan yang saling mengikat antara satu dengan yang lainnya. Hubungan yang saling peduli antar sesama semakin membuat tinggi rasa solidaritas sehingga keamanan dan kenyamanan bisa tercipta.

Mengingat semakin tingginya tingkat individualitas tercermin dari semakin inginnya masyarakat melakukan berbagai hal dengan serba praktis. Seperti yang diungkapkan oleh BMA (2012:10) bahwa semakin banyaknya masyarakat yang mendirikan tarub dengan menyewa tenda secara instan, kemudian menyediakan makanan dengan cara memesan catering. Padahal dimasa lalu tradisi gotongroyong diciptakan oleh nenek moyang dengan memiliki nilai yang sangat luhur. Nilai tersebut bertujuan membantu masyarakat menuju suatu keadaan yang lebih adil nyaman, ketentraman serta keamanan yang terjamin.

Semakin tingginya tingkat indivi dualitas juga semakin membuat diri lebih mementingkan kepentingan pribadi

Orang Rejang Dan Hukum Adatnya dibandingkan kepentingan bersama. Bahkan banyak juga permasalahan pidana seperti kasus jual beli rumah, warisan, perzinahan, dan cepalo serta tabrakan yang umumnya terjadi disebuah kehidupan masyarakat jika tidak diatasi oleh lembaga adat, tentu akan langsung ke jalur hukum. Sementara kita tahu bahwa apapun bentuk masalahnya, jika sudah memasuki ranah hukum maka akan memberikan dampak negatif bagi keduanya salah satunya adalah rasa dendam. Padahal biasanya yang berkonflik jika ditelusuri masih terkait antara dua keluarga besar.

Guna menekan tingginya kerugian baik secara materil maupun imateril maka dalam sebuah kelompok masyarakat adat akan membentuk suatu kesepakatan dalam mencapai ketenangan dalam hidup ber masyarakat dan memberikan sanksi jika ada yang melanggar dan ini dikenal dengan istilah hukum adat. Kadirman (2009:2) menguraikan pengertian hukum adat yakni norma yang tumbuh dan berkembang serta dipatuhi oleh masyarakat adat, bertujuan untuk menciptakan kedamaian dalam arti terciptanya ketentraman dan ketenangan, yang menimbulkan sanksi bagi yang melanggarnya. Di dalam hukum adat mengandung nilai-nilai kekeluargaan, kego tongroyongan, musyawarah, mufakat, kepa tutan, magis, religius arif dan bijaksana dalam menyelesaikan setiap persoalan yang timbul dalam masyarakat.

Adanya hukum adat Rejang dilaksanakan oleh masyarakat hukum adat Rejang dengan jenang kutei sebagai penanggung jawab untuk menyelesaikan berbagai persoalan yang terjadi di dalam masyarakat. Berdasarkan hasil penelitian Iriani dan Metha (2008:4) dikatakan bahwa peran lembaga adat dalam menyelesaikan setiap permasalahan khususnya yang terjadi di Kelurahan Air Rambai, Kecamatan Curup Kabupaten Rejang Lebong sudah sangat tinggi perannya. Semua permasalahan sudah dapat diatasi dengan musyawarah tanpa diakhiri dengan rasa dendam, justru menjadi sebuah ikatan persaudaraan yang kuat.

Kabupaten Rejang Lebong meru pakan sebuah kabupaten yang terdiri dari berbagai macam etnis di dalamnya. Namun begitu, orang Rejang merupakan orang yang sangat dominan yang ada di kabupaten ini. Keberadaan hukum adat orang Rejang juga berlaku kepada seluruh 
suku bangsa yang ada di sini. Oleh karena itu, dalam artikel ini akan dilihat siapakah orang Rejang dan bagaimana mereka menjadikan Kelpeak Ukum Adat Ngen Ca'o Kutei Jang Kabupaten Rejang Lebong sebagai pedoman dalam kehidupan berma syarakatnya. Padahal hukum positif atau hukum negara berlaku di setiap daerah dimanapun berada selama itu menjadi wilayah Indonesia dan tak terkecuali bagi masyarakat di kabupaten ini. Pentingnya melihat orang Rejang dengan pedoman hukum adat tersebut adalah untuk melihat bagaimana peran dari jenang kutai sebagai pemimpin adat, kemudian bagaimana masyarakat menjalankan kehidupan berma syarakatnya berdasarkan pedoman ter sebut.

Kajian ini bertujuan untuk mengungkapkan sejumlah cara orang Rejang dalam berinteraksi dengan ma syarakat berpedoman dengan hukum adat. Hukum adat dijadikan sebagai pedoman karena hukum adat lahir dari kearifan lokal masyarakat dalam menjalankan nilai-nilai dan norma yang diajarkan oleh nenek moyang agar terbentuknya kehidupan yang damai. Menurut Iriani dan Metha (2008:5) bahwa hukum adat dipilih oleh masyarakat Rejang dalam menyelesaikan permasalahan secara musyawarah dan berakhir dengan perdamaian. Tidak ada lagi permusuhan karena kita adalah saudara. Suatu keadaan yang sudah cukup jarang disaat era globalisasi menghadang adat istiadat kita.

\section{B. METODE PENELITIAN}

$\mathrm{M}$ etode penelitian adalah metode kualitatif dengan teknik pengum pulan data berupa studi literatur dan wawancara dengan informan serta observasi di lapangan Menurut Miles dan Huberman yang dilakukan dalam proses analisis dalam penelitian kualitatif adalah pengumpulan data, reduksi data, penyajian data dan penarikan kesimpulan. Pada interpretasi data dilakukan baik dari sudut pandang peneliti maupun dari masyarakat pendukungnya. Hal ini bertujuan untuk mendapatkan gambaran lokasi penelitian. Informan dalam penelitian ini terdiri dari informan kunci dan informan biasa. Informan kunci dalam penelitian ini adalah seorang

41 | P a g e hakim desa. Sedangkan informan biasa adalah para aparat desa, pihak keluarga besar pengantin, serta sepasang pengantin baru ketika peneliti melakukan kegiatan penelitian. Sedangkan teknik pengumpulan data dilakukan dengan beberapa tahap yakni observasi, wawancara, dokumentasi, dan analisis data.

\section{TEMUAN DATA DAN PEMBAHASAN}

\section{Orang Rejang}

Iriani dan Metha (2008:25) mengungkapkan bahwa berdasarkan tambo, suku Rejang berasal dari Sutan Sriduni yang menurunkan empat ketumbai , dan kemudian empat ketumbai tersebut masingmasing membentuk keluarga batih dan akhirnya berkembang menjadi keluarga luas yang mempunyai asal usul keluarga yang jelas. Berdasarkan sejarahnya dikatakan bahwa satu ketumbai terdiri dari keluarga luas mencapai sembilan keturunan. Ter dapat larangan menikah dalam satu ketumbai, tetapi jika itu tetap terjadi maka ia keluar dari ketumbainya dan masuk pada ketumbai pasangannya.

Banyak perdebatan mengenai asal usul orang Rejang salah satunya yakni yang ditulis oleh Jhon Marsden seorang Residen Inggris di Lais tahun 1775-1779 yang dalam laporannya menceritakan tantang empat petulai yakni Jurukalang (joorcalang), Berem mani (Bermani), Selopo (Selupu), dan Toobey (Tubai). Berdasarkan berbagai data historis dan tembo-tembo Rejang serta cerita rakyat dikatakan bahwa orang Rejang menempati wilayahnya di daerah Lebong (Iriani, 2008,Rusli, 2007, Siddik, 1980). Sebelum dinamakan Lebong maka tanah yang ditempatinya dinamakan Renah Se

2 Ketumbai jika dibandingkan dengan adat Minangkabau adalah setara dengan saparuik. Perbedaanya dalam adat Minangkabau garis keturunan ditarik dari garis ibu, sedangkan di Rejang garis keturunan ditarik dari garis bapak. Sebelum berubah menjadi ketumbai, istilah rejang mengena keluarga luas yang terdiri dari 9 keturunan yang masih jelas ini dikenal dengan istilah ketembai. Tidak diketahui apa sebab terjadinya perubahan penyebutan istilah tersebut.

Orang Rejang Dan Hukum Adatnya 
kelawai yang dipimpin oleh empat Raja atau Ajai yakni Ajai Bitang di dusun Belabai Lebong marha suku IX sekarang, Ajai Begeleng Mato di Kutai Belek Tebo Lebong, marga suku VIII sekarang, Ajai Siang di dusun Siang Lekat Lebong, marga jurukalang, dan Raja Tiea Keteko di dusun Bandar Agung Lebong, marga suku IX sekarang. Orang Rejang dari awal dikenal memiliki adat istiadat di bawah pimpinan ajai tersebut.

Menurut Iriani dan Metha (2008:41), Kadirman (2007:3), dan Siddik (1980) dikatakan bahwa pada masa lalu orang Rejang telah memiliki lembaga adat disebut kutai latet yang dipimpin oleh kepala kampung (potal) yang terdiri dari ketuai sukau, golongan laki-laki lanjut usia, para tukang lungus (dukun-dukun), dan cendikiawan. Di kutai latet diadakan persidangan dalam menyelsaikan setiap perkara. Pada masa lalu itupun dikenal hukum adat yang berlaku sangat keras, yakni siapa yang melanggar hukum adat maka akan langsung dibunuh. Saat ini tidak lagi itu diberlakukan melainkan berlaku hukum adat membunuh membangun, yang artinya si pelaku bisa membayar denda dengan sejumlah emas atau perak sesuai dengan keputusan jenang kutai. Jadi sudah dari sejak masa lalu orang Rejang dikenal sebagai masyarakat hukum adat yang disebut kutei. Mereka tergabung dalam sekumpulan manusia yang hidup bersama, memiliki kepentingan dan tujuan hidup yang sama, dan memiliki ketertiban dan memiliki hukum yang dijalani oleh penguasa dari masyarakat itu sendiri yang pimpinannya disebut tuwei kutei. Seorang ketuwei kutei menurut Kadirman (2007:8) tidak bisa secara sembarangan dipilih, syarat utama pada waktu itu adalah keturunan pertama dari orang yang mendirikan kutei. Syarat lain adalah harus orang berakal, dengan tujuan agar tidak mudah terhasut dengan pikiran-pikiran orang lain, beriman agar tidak mengikuti kata orang saja, berharta agar ia tidak tamak, memiliki hati yang sabar, baik, tidak kasar dan tidak pendendam. Ketentuan ini seyogyanya tetap berlaku sampai saat ini dalam pemilihan jenang kutei.

Suku Rejang adalah suku yang tersebar di berbagai daerah di propinsi Bengkulu, yakni di Kabupaten Rejang Lebong, Kabupaten Kepahiyang, Kabupaten
Bengkulu Tengah, Kabupaten Bengkulu Utara dan juga Kabupaten Lebong. Masyarakat Rejang yang tersebar di berbagai kabupaten di Bengkulu ini tidak hanya memiliki hukum adat yang sudah berlaku sejak lama, tetapi juga memiliki kekayaan adat budaya. Salah satunya yakni memiliki bahasa yakni bahasa Rejang de ngan huruf rikung atau dikenal dengan sebutan huruf ka ga nga.

Kebudayaan yang dimiliki oleh orang Rejang sangat menjadi acuan dalam kehidupannya sehingga nilai-nilai dari kebudayaan tersebut tercermin dalam hukum adat yang dipedomani dalam kehidupan bermasyarakat.Seperti yang dike mukakan oleh Hamengkubuwono (2014:6) bahwa fungsi kebudayaan adalah sebagai pedoman dan pengarah hidup bagi manusia, sehingga ia mengerti bagaimana harus bertindak, bersikap, berperilaku, baik secara individu maupun berkelompok agar tidak terjadi goncangan-goncangan sosial. Oleh karena itu untuk menghindari terjadinya hal-hal yang berakibat buruk maka manusia harus berpedoman pada nilai-nilai, norma-norma dan segala ke biasaan yang berlaku di masyarakat. Pada masyarakat Rejang berpedoman pada Kelpeak Ukum Adat Ngen Ca'o Kutei Jang Kabupaten Rejang Lebong. Jika terjadi permasalahan dalam masyarakat Rejang maka akan diselesaikan oleh jenang kutai sebagai hakim desa yang bertanggung jawab menyelesaikan setiap perkara. Hukum adat Rejang berlaku untuk semua orang Rejang. Yang dikatakan sebagai orang Rejang dalam hal ini adalah orang yang bertempat tinggal dan hidup di tanah Rejang. Siapapun orang yang memijak tanah Rejang, harus tunduk kepada hukum adat Jang dimana langit dipijak di situ langit dijunjung.

\section{Pedoman Kelpeak Ukum Adat Ngen Ca'o Kutei Jang Kabupaten Rejang Lebong}

Hukum adat dan norma serta tata cara kehidupan dalam Kabupaten Rejang Lebong berada di di bawah kelapa pinang yang disebut dengan istilah adat ninik menetei pun pegong pakie beak nyoa pinang. Artinya adat nenek meniti pohon adat istiadat di bawah kelapa pinang. Adapun adat yang diatur dalam ketentuan tersebut (BMA, tt:2-23), yakni: 
1. So samo artinya masyarakat Rejang bersandarkan kepada nilai agama yakni adat bersendikan sara', sara' bersendikan Kitabullah.

2. Kamo bamo artinya masyarakat mengakui hak bersama adalah milik bersama, yang menjadi utama adalah prinsip kekeluargaan.

3. Tiep-tiep ade do pengenea, adat makeu te'ang ngen sudo artinya setiap perbuatan baik bersifat hukum, adat dan hukum adat mengakui dengan azas terang dan tunai. Maksudnya tidak dilakukan secara sembunyi melainkan harus ada saksi. Contohnya pernikahan anak Rejang dilakukan dihadapan masyarakat (kutel).

4. Adat tulung menulung artinya saling menolong baik dalam keadaan senang atau pun susah. Seperti ungkapan masyarakat Rejang $m u$ eak kakane ade, beripit kekeane coa artinya murah dan gampang bagi mereka yang punya dan sulit bagi mereka yang tidak punya.

5. Adat rian beteu mbateu artinya batu membantu yang dikenal dengan bahasa Rejang yakni pinjem artinya ada suatu pekerjaan yang harus dikerjakan oleh masyarakat (kutei). Contoh pekerjaan tersebut yakni menugal padi di kebun, mene gakkan kerangka bangunan rumah, mendirikan tarub, mengambil kayu bakar dan bambu untuk tarub hajatan.

6. Bebanea inde benuo yakni mengambil gambaran dari rotan manau yang jika ingin mengam bilnya harus menelusuri dari bawah. Artinya jika ada suatu permasalahan maka harus dicari pokok perma salahannya terlebih dahulu.

7. Be tutun inde jalei ungkapan yang mengambil dari makna sebuah jala. Jala jika dilihat terkesan rumit, tetapi asalnya adalah dari seutas benang. Jadi kalau melihat permasalahan lihat dari pokok permasalahnnya.

8. Ade lot ade ei istilah yang memperlihatkan gambaran masya rakat Rejang yang kehidupannya berada di pinggiran sungai. Bagi masyarakat sungai merupakan sarana penghubung mengadakan hubungan silaturahmi serta menyam paikan berita atau pesan juga sebagai sarana perekonomian. Jadi sungai mengalir dari hulu ke hilir, jadi masyarakat di hulu harus memperhatikan keadaan yang di hilir.

9. Titik meluo mbeakba melei artinya masalah kecil hitam janganlah kita perbesar. Berlakulah dalam hidup bermasyarakat dengan jiwa pemaaf.

10. Pendak dik sudo, panjang gik igei artinya jika permasalahan sudah diselesaikan janganlah diingat kem bali, jadikan itu sebagai musibah dari Allah yang ada hikmah di dalamnya.

11. Mengemak, mengelak artinya melakukan sesuatu tanpa pamrih tetapi bila tiba waktunya maka wajib kita membantunya.

12. Bekinjem, mengulang artinya meminjam dan mengembalikan ha rus dilakukan sesuai waktu dan kepentingannya.

13. Butang, mengasen artinya kewa jiban berhutang harus membayar.

14. Piutang menimo artinya piutang harus dibayar setelah tiba waktunya.

15. Janjei menunggeu artinya janji harus ditepati.

16. Pecoak bekaping artinya bagi kehidupan masyarakat Rejang yakni apabila ada upaya memecah belah suatu kelompok masyarakat maka harus diupayakan untuk merapatkan kembali.

17. Sumbang betitip artinya jika ada keadaan yang kurang baik, maka alangkah baiknya kita mencoba membantu menyelesaikannya seprti contohnya jika terjadi pertengkatan dalam sebuah keluarga maka diharapkan agar kembali akur baik dilakukan secara upacara adat dan juga cara kekeluargaan.

18. Hak suarang bageak artinya harta benda yang didapat semasa dalam perkawinan. Jika terjadi perceraian maka harta tersebut di bagi dua.

19. Serang nelek artinya harta bawaan dalam perkawinan baik yang dibawa 
oleh istri ataupun suami jika meninggal salah satunya dan tidak memiliki anak maka harus dikembalikan kepada keluarganya.

20. Selang sifetne tegoa artinya meminjam sesuatu yang sifatnya sementara dan tidak menimbulkan akibat hukum peralihan ha se seorang. Contohnya gadai, titipan ataupun mengerjakan lahan perta nian untuk satu dua kali musim tanam.

21. Betimbang samo beneak artinya mengambil keputusan dengan hati nurani terhadap berbagai permasalahan yang dihadapi, agar keputusan yang diambil harus hadil dan bisa dipertanggungjawabkan kepada Allah SWT.

22. Bekilo samo kelengan artinya harus menimbang sama ringan, jadi jangan berbuat curang hanya karena sifat serakah karena itu dibenci oleh masyarakat.

23. Bekulak samo penoak sama artinya menakar sesuai takarannya, jangan sampai terjadi menakar dengan dua takaran karena bagi masyarakat Rejang itu akan mendapat celaka yakni seringkali harimau menam pakkan badannya ke desa. Ini disebut masyarakat Rejang "Bumei panes".

24. Bageak samei kedeu artinya kejujuran sangatlah dikedepankan. Bagi masyarakat hukum adat Rejang, adat telah mengatur bahwa tukang membagi harus mengambil bagiannya paling kemudian.

25. Kaseak bales artinya apapun yang telah diberikan bantuan kepada kita maka kita wajib membalasnya meskipun hanya dengan ucapan terimakasih.

26. Sayang betimbang artinya kepada siapapun kita harus memiliki kasih sayang yang dari lubuk terdalam menyayangi seseorang.

27. Dete tekedong artinya terkait dengan prioritas pekerjaan. Tidak hanya pekerjaan tetapi juga terkait dengan status hukum pernikahan seseorang, jika semendo maka harus mendahulukan keluarga istri.

28. Tuwei be u'ei artinya tua dan muda yang dalam masyarakat hukum adat
Rejang memberikan patokan kepada masyarakat dalam kita melakukan hubungan menempatkan diri. Dalam masyarakat adat Rejang dikenal golongan masyarakat yakni kelompok tun titik/ anak lin (anakanak), kelompok bujang semulen (remaja), kelompok batin anom (suami istri yang usia perka winannya masih muda), dan kelompok tuwei sadei (kelompok pemuka masyarakat/orang tua di desa).

29. Titik jibeak maghep anak, tuwei ati teu di bapak artinya usia anak atau bapak sesuai dengan pengetahuan dan kemampuan seseorang. Tidak hanya berpatokan pada usia.

30. Daleak daging artinya darah dan daging yang terkait dengan hubungan tali darah, jika ada masalah maka tidak boleh meli batkan pihak luar melainkan harus diselesaikan secara interen.

31. Deko seto artinya sejengkal atau sehasta yakni keputusan yang diambil mendahulukan seseorang berdasarkan hubungan seseorang dengan orang lain.

32. Oak pa'ak artinya jauh dan dekat dalam hubungan keluarga dan perkawinan. Terdapat aturan adat dalam perkawinan yakni : per kawinan satu nenek (mecoak ko'on/memecaj periuk), perkawinan satu poyang (mecoak sumbei) dan perkawinan satu muning (mecoak tumbang). Jika terjadi hal demikian maka adat mengatur membayar denda dua ekor kambing.

33. Luweng kelmen artinya siang malam menjadi suatu ketentuan dalam melakukan berbagai hal. Jika dilanggar maka sanksinya pun berbeda. Luweng berarti terang, kelmen berarti gelap, perbuatan luweng adalah perbuatan yang harus dilakukan secara terang.

34. Mu'eak kakane ade, beripit kaka ne coa artinya murah tempatnya bagi yang berpunya dan sulit bagi mereka yang tidak punya. Jadi yang harus dipertimbangkan dalam melakukan suatu hajatan maka harus dipertimbangkan kemampuan ekonomi seseorang. Adat dan 44 | $P$ a g e 
hukum adat harus ditegakkan, namun bagi mereka yang tidak punya harus diberi toleransi atau kemudahan.

35. Keleak tangis idup ngen tangis matie artinya melihat penyebab tangis seseorang apakah tangisan musibah atau tangisan tak berpunya. Kita harus bisa mem bantu agat tangisan tersebut reda.

36. Bepatet bekenek, bejenjang tu'un artinya dalam menyelesaikan suatu pekerjaan harus mengikuti aturan yang telah digariskan seperti menapaki anak tangga.

37. Meli'ing , mendata artinya dalam menyelesaikan suatu persoalan terkadang jalan yang ditempuh harus berliku-liku dan juga ter kadang tidak mengalami kesulitan, namun semua harus ditempuh dalam upaya penyelesaian per soalan dengan baik.

38. Kegong ketibeak baso artinya tata cara pemanggilan seseorang agar diketahui hubungan seseorang dalam adat. Tidak boleh secara sem barangan kita memanggil sese orang.

39. Iben mustei betumbuk artinya tatacara dalam berbicara dengan menyuguhkan sirih terhadap lawan bicara.

40. Kandang jibeak melakeak artinya batas atau pagar dilarang dilangkahi atau dilompati walau ingin lewat. Pengertian pagar bagi masyarakat adat Rejang sangat luas baik pagar di luar rumah ataupun di dalam rumah.

41. Bo jibeak kem'ak artinya kayu beserta dahan dan rantingnya yang ditumpuk pada suatu tempat. Ini adalah sebuah larangan atau batasan sehingga jika dilanggar maka sama halnya ini dengan mencuri dan akan ada hukumannya.

42. Amen nageak, coa buleak mamit igei artinya apapun yang telah diberi kepada orang lain tidak boleh diminta kembali.

43. Uleak tun titik mbeak ite tuwei mileu artinya apabila antara anak-anak ada masalah maka diselesaikan dengan cara baik-baik jangan terbawa emosi, kalau terlalu parah maka serahkan pada orang-orang tua di desa.

44. Tun coa waras kecekno coa dapet ite megong, kesaleakne coa dapet ite mukum, neleak magea asoak basoakne artinya apapun tindakan orang tidak waras menjadi tanggung jawab sepenuhnya terhadap ke luarganya. Hal ini sesuai dengan hukum adat Rejang yang dikenal dengan royot dan peroghon, yakni saudara sedarah daging artinya apapun yang terjadi baik atau buruk maka akan dinikmati atau ditang gung segala resikonya.

45. Paket coa nam nembin lem kutei artinya pangkat yang dimiliki yang diberikan oleh negara tidak mempengaruhi kewajibannya seba gai menantu di dalam keluarga.

46. Tangen menetok, baeu musung artinya apabila tangan kita memotong maka bahu akan memikulnya. Segala perbuatan yang kita perbuat maka kita yang menanggung segala resikonya.

47. Saleak suko butang, gawa suko matie artinya dalam menjalankan kehidupan di tengah masyarakat terkadang ada salah dan khilaf dan harus bersedia menerima dan menjalankan hukuman adat yang telah ditentukan.

48. Ayak miling tenlen kileak biyoa inoa artinya sebelum berbicara telan air liur terlebih dahulu. Hal ini harus dilakukan agar tidak terjadi hal-hal yang mungkin berakibat fatal dari apa yang telah kita katakan.

49. Ayak bekenea, kabo tukuk artinya sebelum bertindak atau berbuat maka diminta kita untuk meraba tengkuk dulu yakni memberi kesempatan kepada otak untuk berfikir guna menghindari perbuatan negatif.

50. Mbeak mbin sifet lalang biding dalen artinya sifat ilalang yang tidak memiliki pendirian hendaknya jangan ditiru oleh manusia, kita harus memiliki pendirian yang teguh apalagi jika kita adalah seorang 
yang diberi amanah oleh masyarakat.

51. Tiep-tiep tun menyereak makeu kesaleak, wajib ite temimo artinya apapun kesalahan yang pernah dilakukan oleh seseorang kemudian dia telah memohon maaf dan melakukan dendanya, maka sudah seharusnya dimaafkan secara ikhlas. Janganlah memberatkan beban mereka yang telah berbuat salah tersebut.

52. Cuwuo-cuwuo samo laleu, denongdenong samo belek artinya suatu tindakan yang menurut adat hal tersebut dilarang.

Itulah sejumlah ketentuan adat yang

dimiliki oleh masyarakat adat Rejang yang harus dipatuhi. Terlihat bahwa semua hal yang berkaitan dengan hubungan masya rakat sudah diatur jelas dalam ketentuan adat tersebut. Jadi persoalan apapun bentuknya yang terjadi dalam masyarakat baik pelanggaran berat ataupun ringan diselesaikan dengan hukum adat. Hal ini bertujuan agar tidak terjadi konflik yang berkepanjangan sementara kita adalah satu yakni orang Rejang.

Namun begitu terdapat suatu ungkapan bagi masyarakat Rejang bahwa apapun permasalahn yang terjadi di tengah masyarakat dapat diselesaikan dengan berdasar pada adat tigo persilo (dalam Iriani dan Metha, 2008:47-48) yakni :

1. Adat Temenggung, yakni peraturan adat yang memberikan denda berdasarkan besar kecilnya kesala han atau pelanggaran yang dilakukan oleh seseorang.

2. Adat Singo Rajo, yakni peraturan adat yang menyatakan bahwa dalam menyelesaikan suatu per soalan selalu bersifat obyektif tanpa memandang latar belakang atau status si pelanggar hukum.

3. Adat Iman Mergageak Tiung Mergalo, artinya orang yang tidak mau disalahkan. Hitam dikatakan putih, putih dikatakan hitam, akhirnya Tanjung genting tambun tulang, air keruh berkubang basah.

\section{Lembaga Adat dan Hukum adat}

Lembaga adat yang terdapat di Kabupaten Rejang Lebong yakni Badan Musyawarah Adat tingkat Kabupaten, tingkat Kecamatan dan yang terendah di tingkat Kelurahan atau Desa. Adapun dasar hukum pembentukan Badan Musyawarah Adat tingkat Kelurahan atau Desa adalah Surat Keputusan Bupati Rejang Lebong No. 309 tahun 2007 tentang Pengangkatan Pengurus Badan Musyawarah Adat Desa/ Kelurahan dalam Kabupaten Rejang Lebong yang menyataan bahwa untuk melestarikan adat istiadat dalam Kabupaten Rejang Lebong perlu membentuk Badan Musya warah Adat di tingkat desa atau kelurahan. Adapun jumlah anggota pengurus yakni sebanyak 15 (lima belas orang) yang masing-masing mempunyai tugas yakni sebagai penasehat 2 (dua orang), wakil ketua, sekretaris, wakil sekretaris, benda hara, bidang adat istiadat 2 (dua orang), bidang sejarah kepurbakalaan 2 (dua orang), bidang aksara dan seni budaya 2 (dua orang), bidang bina program, dan bidang humas/ dokumentasi.

Pihak yang memiliki peran dalam menyelesaikan permasalahan yang terjadi di tengah masyarakat yang merupakan perpanjangan tangan dari BMA adalah jenang kutai atau hakim desa. Adapun dasar hukum ketentuan ini adalah berasal dari Surat Keputusan Bupati Rejang Lebong Nomor 58 Tahun 2005 yang berisi tentang pelaksanaan hukum adat Rejang dan Surat Keputusan Bupati Rejang Lebong Nomor 93 Tahun 2005 tanggal 17 Maret 2005 yang ditindaklanjuti oleh BMA Kabupaten Rejang Lebong dengan mengeluarkan Surat Nomor 26a/BMA/III/2005 tanggal 23 Maret 2005. Adapun isi surat tersebut menyatakan bahwa setiap permasalahan yang menyang kut pelangaran hukum adat diselesaikan di Kelurahan dan ditangani oleh jenang kutai dengan memakai hukum adat.

Jenang kutai menurut ketentuan adat dalam BMA,(tt:42-43) dan Arios,(2006:79) dalam satu desa atau kelurahan adalah terdiri dari empat suku ditambah dengan kepala desa selaku Raja. Jenang kutai memiliki kewajiban untuk menerima dan menyelesaikan setiap per buatan atau tindakan yang melanggar adat atau tatacara dalam masyarakat, yang disampaikan kepada mereka, baik yang disampaikan oleh hulu balang, ketua kutei atau yang disampaikan pimpinan desa lainnya, ataupun yang disampaikan oleh anggota masyarakat/ pengadu kepada mereka. Jenang kutei dalam melaksanakan 
tugasnya dapat bertiga atau berlima, sedangkan apabila kasus itu sedang dihadapi oleh salah satu suku yang terlibat, maka jenang kutai dengan suku yang sama tidak boleh menjadi anggota majelis hakim desa.

Kedudukan jenang kutai sangat memiliki peran yang tinggi dalam memutus kan suatu perkara dengan berdasarkan pada pedoman yang berlaku. Apapun dilakukan oleh jenang kutai untuk menda patkan keputusan yang seadil-adilnya agar tidak menimbulkan dendam bagi kedua belah pihak. Keputusan yang dibuat bersifat mutlak, tidak bisa diganggu gugat oleh siapa pun. Keputusan juga dapat dibuat dengan pertimbangan hukum Islam dan hukum negara, dan jika tidak diterima maka bisa diadukan keberatannya kepada Bupati sebagai pimpinan tertinggi di Kabupaten Rejang Lebong.

Orang Rejang di tanah Rejang umumnya sangat mematuhi segala hasil keputusan yang dibuat oleh jenang kutei. Hal ini dikarenakan keputusan tersebut benar-benar dihasilkan dengan pemikiran dan hati nurani yang terdalam karena harus bisa dipertanggungjawabkan kepada Tuhan Yang Maha Esa. Hal ini seperti yang telah diatur dalam pedoman yang berbunyi Betimbang samo beneak artinya mengambil keputusan dengan hati nurani terhadap berbagai permasalahan yang dihadapi, agar keputusan yang diambil harus adil dan bisa dipertanggungjawabkan kepada Allah SWT.

Bagi orang Rejang yang terkait permasalahan maka akan menerima segala keputusan jenang kutei seperti yang terdapat dalam pedoman bahwa Tiep-tiep tun menyereak makeu kesaleak, wajib ite temimo artinya apapun kesalahan yang pernah dilakukan oleh seseorang kemudian dia telah memohon maaf dan melakukan dendanya, maka sudah seharusnya dimaaf kan secara ikhlas. Janganlah memberatkan beban mereka yang telah berbuat salah tersebut. Oleh karena hal ini sangat dimengerti oleh masyarakat, maka mereka menerima dengan ikhlas segala keputusan tersebut.

Seperti contoh kasus yang terjadi di Kelurahan Air Rami dalam Iriani dan Metha (2008:58) yakni terjadi pelanggaran adat (delik adat). Pelanggaran ini terjadi dalam bentuk pelanggaran asusila yang terbukti dari tidak sesuainya usia anak yang lahir dengan usia pernikahan mereka. Anak lahir sebelum dalam usia pernikahan yang kurang dari 6 (enam) bulan atau dikenal dengan istilah anak lahir dibawah bulan. Pelanggaran ini kedua belah pihak dikena kan denda berupa "cuci kampung". Adapun proses penyelesaianya adalah dengan adanya pengaduan dari masyarakat terlebih dahulu kepada BMA atau ketua RT. Pengaduan tersebut tidak bisa langsung diterima tetapi harus disertai bukti dengan mencari data atau informasi tentang pernikahan mereka. Setelah terbukti maka kedua belah pihak akan dipanggil kemudian disidangkan di kantor lurah dengan dihadiri kepala desa, ketua BMA, dan jenang kutei. Setelah disidang maka dikenakan sanksi "cuci kampung".

Contoh lain yakni ketika adanya korban tabrakan yang menyebabkan tidak hanya cedera melainkan sampai nyawa melayang tetap diselesaikan oleh jenang kutei kerjasama dengan Forum Kemitraan Polisi Masyarakat (Iriani dan Metha, 2008:71). Kejadian ini sering terjadi di Kelurahan Air Rambai yang memang merupakan jalan lintas Sumatera BaratBengkulu Jika terjadi kasus tabrakan yang menyebabkan luka dan dirawat maka pihak kepolisian setelah ada yang melapor akan menahan kendaraan tersebut, dan persoalan kemudian dikembalikan kepada jenang kutai. Oleh jenang kutai kedua belah pihak dipanggil melalui surat, kemudian hadir dalam persidangan dan mengambil jalan tengah. Jika telah sepakat dengan keputusan jenang kutei maka dibuatlah perjanjian damai yang ditandatangi jenang kutei. Berbekal surat itu maka kendaraan yang ditahan pihak kepolisian bisa diambil setelah membayar sejumlah biaya sesuai di kepolisian. Oleh karena itu umumnya yang terlibat kasus tabrakan ingin urusan ini secepat mungkin agar biaya yang harus dikeluarkan tidak terlalu mahal. Karena belum lagi biaya perawatan si korban yang harus ditanggung.

Terdapat jenis-jenis denda dalam hukum adat Rejang yang dikenal dengan sebutan bangun, yakni (1) bangun sesalan, (2) bangun penuh, (3) bangun mayo. Tidak hanya itu saja, biasanya keluarga pelaku 
akan membawa segala keperluan upacara jika korban sampai meninggal dunia. Kemudian melaksanakan doa perdamaian dengan dihadapan masyarakat bahwa mereka telah berdamai dan mulai saat itu mereka adalah satu keluarga. Apapun yang terjadi tidak lagi menjadi orang lain dan segala suka dan duka selalu berbagi. Hal ini menjadi pilihan bagi masyarakat suku Rejang dibandingkan dengan berurusan dengan hukum negara yang tidak hanya menghabiskan uang yang banyak juga menimbulkan dendam. Sedangkan jika diselesaikan dengan hukum adat, maka tidak hanya biaya yang bisa dikompromikan, perasaan dendam pun tidak ada karena hal itu bisa terjadi pada siapapun dan sudah merupakan ketentuan Allah dan masyarakat harus menyikapinya dengan kepala dingin.

Setiap kasus yang diselesaikan oleh jenang kutei sebenarnya sama halnya dengan proses hukum negara yakni harus disertai bukti, saksi dan berita acara perdamaiannya, kemudian hal itu disam paikan kepada Bupati dan ketua BMA Kabupaten. Ini sesuai dengan Surat Keputusan Bupati Rejang Lebong No. 338 tahun 2005 yang menyatakan bahwa jenang kutei dalam melaksanakan segala tugasnya bertanggungjawab kepada bupati Rejang Lebong, melalui BMA desa, BMA kecamatan dan BMA kabupaten.

Sampai saat ini masyarakat Rejang khususnya di Kabupaten Rejang Lebong sudah banyak menyelesaikan masalah dalam kehidupan bermasyarakatnya dengan berpedoman hukum adat. Perselisihan, perceraian, hukum waris, masalah pidana dan perdata bagi masyarakat diselesaikan dengan damai dan hasilnya adil karena berlakuan hukum adat Rejang yang dipakai ada tegak lurus dan tidak memihak ke sebelah manapun. Dengan hasil berlakuan hukum tersebut maka habislah dendam kesumat yang tidak baik sebagaimana pepatah adat mengatakan bukan menyen cang labu ke batu dan tidak pula menyencang labu ke banyu (kea air) parangnya diangkat nampak tidak berbekas lagi (BMA, 2012:30). Satu lagi yang menguatkan orang Rejang untuk mentaati hukum adat yang berlaku adalah untuk menjalankan setiap sanksinya, jika tidak maka akan berlaku hukum tikam dalam artian luas yakni hukuman dikucilkan dari masyarakat dikampung bagi si pelaku dan seluruh keluarga dan kerabatnya. Hukuman inilah yang sangat dianggap paling memberatkan, oleh karena itu biasanya setiap sanksi yang dijatuhkan akan dibayar semampu pelaku dan atas pertimbangan keadaan si pelaku. Hal inilah yang menyebabkan hukum adat bersifat manusiawi dan sangat dihormati oleh orang Rejang sampai saat ini.

Pedoman hukum adat juga mengatur segala adat istiadat tradisi yang dijalani oleh masyarakat Rejang. Di setiap tradisi upacara maka harus selalu menggunakan sirih. Seperti yang diatur dalam adat nenek meniti pohon adat istiadat di bawah kelapa pinang no 39 yakni Iben mustei betumbuk artinya tatacara dalam berbicara dengan menyuguhkan sirih terhadap lawan bicara. Sirih ini tidak bisa diperlakukan seenaknya, karena sirih adalah simbol penghormatan. Tujuan memberikan sirih harus sesuai dengan tahapan dalam setiap jenis upacara. Menurut Kadirman (2009:4) sirih atau dikenal dengan istilah iben bagi masyarakat Rejang merupakan sarana pembuka jalan/ awal dari semua proses yang akan ditempuh menyangkut kepentingan mereka masing-masing tergan tung jenis acara apakah upacara adat dalam bentuk penerimaan tamu agung ataupun kegiatan penyelesaian masalah-masalah hukum.

Aturan adat terdapat dalam tradisi perkawinan dimulai dari bekulo (berunding) yang merupakan tahapan sebelum upacara perkawinan sampai pada acara tempung sematen ngen ngenyan yang merupakan puncak acara pernikahan sudah diatur pula dalam pedoman hukum adat Rejang. Setiap tahapan apa yang harus dilaksanakan, bagaimana pelaksanaan dan siapa yang melaksanakannya sudah ditetapkan. Tem pung sematen ngen ngenyan misalnya, ini adalah satu tahapan yang wajib dilaksanakan oleh sepasang pengantin setelah akad nikah selesai. Inti dari tradisi ini adalah sebagai penghormatan pada leluhur, orang tua dan masyarakat yang telah mengizinkan mereka menikah untuk mengarungi bahtera rumah tangga. Rumah tangga yang akan dilalui ini tidaklah akan berjalan mulus tetapi akan terdapat berbagai masalah di dalamnya. Oleh karena itu diharapkan sepasang pengantin ini siap dengan segala doa restu dan perlindungan dari semua untuk bisa bertahan dari segala 
ujian yang ada di dalamnya. Percikan air tawar adalah sebuah simbol agar dapat selalu dengan kapala dingin dalam menghadapi berbagai persoalan di dalam menjalani bahtera rumah tangga ini (Silvia Devi dan Eny. Ch, 2011).

Ketentuan pakaian adat bagi wanita dan laki-laki sudah diatur dalam pedoman hukum adat sesuai dengan kedudukan, dan bentuk upacara yang akan dihadiri. Ketentuan dalam pelaksanaan kedurai agung dan juga tari-tarian sakral secara lengkap diatur dalam pedoman tersebut. terpenting yang harus diutamakan adalah pemahaman orang Rejang bahwa adat istiadat yang mereka miliki berpedoman dengan ketentuan hukum adat yang telah dibuat hendaknya dipatuhi, dipertahankan dan terus dilestarikan dan norma yang ada di dalamnya dijunjung tinggi.

\section{Kesimpulan}

$\mathrm{P}$ edoman Kelpeak Ukum Adat Ngen Ca'o Kutei Jang Kabupaten Rejang Lebong yang menyangkut berbagai adat istadat yang berlaku di masyarakat Rejang sudah dilaksanakan semaksimal mungkin dalam realitanya. Peran jenang kutei sebagai hakim desa yang menangani segala persoalan yang terjadi jika terdapat pelanggaran adat oleh masyarakat Rejang.
Sedangkan BMA memiliki peran yang aktif dalam setiap penyelenggaraan adat di tengah masyarakat. BMA sudah menge luarkan pedoman tersebut tinggal pelaksa naanya mengacu pada pedoman tersebut. Pedoman hukum adat ini dibuat tidak hanya sebagai usaha menyelesaikan setiap masalah, tetapi lebih dari itu adalah sebagai usaha untuk tetap meletarikan segala kearifan lokal yang dimiliki oleh orang Rejang demi lestarinya nilia-nilai kegotong royongan, nilai mufakat, dan terutama sekali nilai kekeluargaan yang sangat kental. Jika kita sudah mengutamakan keselamatan dan kerukunan dalam keluarga maka akan mudah membentuk jiwa masyarakat yang selalu bersatu mempertahankan keutuhan dari derasnya arus negatif globalisasi.

\section{E. TERIMA KASIH}

D enulis mengucapkan terima kasih kepada pimpinan Balai Pelestarian Nilai Budaya Sumatera Barat yang telah mengizinkan dan dukungan finansial pada penelitian ini dan dukungannya dalam keikutsertaan dalam kegiatan ilmiah ini. Penulis juga berterima kasih kepada Undri, SS, Msi dan Muhammad Hidayat, S.Sos, S.Hum, M. Hum atas diskusinya yang bermanfaat bagi penulis.

\section{Daftar Pustaka}

\section{Makalah}

Kadirman, 2009. Makalah : Strategi Pemberdayaan dan Implementasi Adat Istiadat dan Hukum Adat Rejang Lebong dalam Konteks Otonom Daerah di Kabupaten Rejang Lebong. Disampaikan pada Seminar "Eksistensi Hukum Adat dan Masyarakat Hukum Adat di Era Otonomi Daerah" yang diselenggarakan oleh Balai Pelestarian Sejarah dan Nilai Tradisioanl Padang dan BMA Rejang Lebong 20 Mei 2009.

Kadirman, 2007. Makalah : Lembaga-Lembaga Pada Masyarakat Rejang Sebelum Kemerdekaan.Disampaikan pada Seminar Sejarah dan Budaya Rejang di Curup tanggal 15-16 Mei 2007 diselenggarakan oleh Balai Pelestarian Sejarah dan Nilai Tradisional Padang.

Arios, RL. 2009. Makalah : Orang Jawa di Kabupaten Rejang Lebong :Sejarah dan Dinamika Interaksinya dengan Orang Rejang. Disampaiakan pada Seminar Sejarah dan Budaya Rejang di Curup tanggal 15-16 Mei 2007 diselenggarakan oleh Balai Pelestarian Sejarah dan Nilai Tradisional Padang.

Kadirman, 2009. Makalah : Strategi Pemberdayaan Budaya Rejang dalam Konteks Otonomi Daerah di Kabupaten Rejang Lebong. Disampaikan pada Rapat 
Koordinasi BPSNT Padang dengan stakeholder di Propinsi Bengkulu 23-25 November 2009.E

Effendi, Nusyirwan. 2016. Makalah : Penguatan Lembaga Adat sebagai Strategi Pelestarian Nilai Budaya. Disampaikan pada Rapat Teknis Pelestarian Nilai Budaya BPNB Sumatera Barat tanggal 23-25 Mei 2016 di Bukitinggi

Hamengkubuwono, 2014. Makalah Tantangan Adat dan Budaya Rejang di Kabupaten Rejang Lebong pada Era Kekinian. Disampaikan pada Kegiatan FGD Kurikulum Muatan Lokal di Kabupaten Rejang Lebong 24-26 Februari 2014.

Santoso, 2014. Makalah Peran BMA dalam Penyusunan Kurikulum Muatan Lokal di Kabupaten Rejang Lebong. Disampaikan pada Kegiatan FGD Kurikulum Muatan Lokal di Kabupaten Rejang Lebong 24-26 Februari 2014.

Rusli, 2007. Makalah : Asal Usul Bangsa Rejang.Disampaikan pada Seminar Sejarah dan Budaya Rejang di Curup tanggal 15-16 Mei 2007 diselenggarakan oleh Balai Pelestarian Sejarah dan Nilai Tradisional Padang.

Buku

Badan Musyawarah Adat (BMA) Kabupaten Rejang Lebong, Kelpeak Ukum Adat Ngen Riyan Ca'o Kutei jang Kabupaten Rejang Lebong, Curup : BMA Kabupaten Rejang Lebong

Badan Musyawarah Adat (BMA) Rejang Lebong, 2012.Lepeak Hukum Adat Jang Kabupaten Rejang Lebong. Curup : BMA Kabupaten Rejang Lebong

Devi, Silvia dan Eny Chrystyawati, 2011. Syair "Tempung Sematen ngen Ngenyan" dalam Upacara perkawinan Suku Bangsa Rejang. BPSNT Padang Press.

Kadirman, 2004. Ireak Ca'o Kutei Jang,Jakarta : Balai Pustaka

Koentjaraningrat, 1997. Pengantar Antropologi Pokok-Pokok Etnografi Jilid II, Jakarta : Rineka Cipta

Ratna, Nyoman Kutha, 2010. Metodologi Penelitan Kajian Budaya dan IImu-IImu Sosial Humaniora Pada Umumnya. Yogyakarta : Pustaka Pelajar.

Siddik, Abdullah, 1980. Hukum Adat Rejang, Jakarta : Balai Pustaka

Iriani, 2004. Tatakrama Suku Bangsa Rejang di Kecamatan Curup Propinsi Bengkulu. Padang : Balai Kajian Sejarah dan Nilai Tradisional Padang

Iriani, 2008. Perdamaian Adat :Mekanisme Penyelesaian Permasalahan di Air Rambai Laporan Penelitian. Padang : Balai Pelestarian Sejarah dan Nilai Tradisional Padang.

M.Ikram, dkk.2004. Bunga Rampai Melayu Bengkulu.

Soekanto, Soerjono.1983. Hukum Adat Indonesia. Jakarta : Rajawali Press

Dinas Pariwisata dan Kebudayaan Rejang Lebong, 2003. Adat Istiadat Kabupaten Rejang Lebong.Bengkulu : Dinas Dinas Pariwisata dan Kebudayaan Rejang Lebong. 